\title{
Pathological effects of Peroderma cylindricum (Copepoda: Pennellidae) on the kidneys of its pilchard host, Sardina pilchardus (Osteichthyes: Clupeidae), from Tunisian coasts
}

\author{
Samia Becheikh ${ }^{1}$, Viviane Rousset ${ }^{2}$, Fadhila Maamouri ${ }^{1}$, \\ Oum Kalthoum Ben Hassine ${ }^{1}$, André Raibaut ${ }^{3, *}$ \\ ${ }^{1}$ Laboratoire de Biologie et Parasitologie Marines, Faculté des Sciences, Université de Tunis II, \\ Campus Universitaire El Menzah, 1060 Tunis, Tunisia \\ ${ }^{2}$ Laboratoire de Parasitologie et Immunologie, Université Montpellier II, Place Eugène Bataillon, \\ F-340955 Montpellier Cedex 5, France \\ ${ }^{3}$ Laboratoire de Parasitologie Comparée, UMR CNRS 5555, Station Méditerranéenne de l'Environnement Littoral, \\ Université Montpellier II, 1, quai de la Daurade, F-34200 Sète, France
}

\begin{abstract}
Peroderma cylindricum (Heller, 1865) is a pennellid copepod, common on the pilchard Sardina pilchardus (Walbaum, 1792), from the Tunisian coasts. The cephalic area of the parasite displays an important network of cephalic rootlets with dichotomic ramifications inserted mainly into the anterior part of the host's kidney. A histological study' shows that these formations alter the kidney's structure. This is confirmed by the destruction of excretory structures sometimes leading to the appearance of haematoma. The possible role of these cephalic rootlets is compared with their role in other parasitic crustaceans displaying the same formations. It is probable that the presence of this parasite induces mortality in pilchards, mainly 1 to 2 yr old.
\end{abstract}

KEY WORDS: Peroderma cylindricum - Sardina pilchardus · Histopathology · Kidneys

\section{INTRODUCTION}

The family Pennellidae includes parasitic copepods whose adult females are more or less deeply inserted into the body of their vertebrate host (fish or cetacean). The insertion can take place in the dermis or in the muscular mass of the host without any preferential area, as is the case for the genus Pennella Oken, 1816. Other pennellids target specific organs, such as the eye [Phrixocephalus cincinnatus Wilson, 1908 and Lernaeenicus sprattae (Sowerby, 1906)], the gill arch [Lernaeocera lusci (Bassett-Smith, 1896)], the bulbus arteriosus and the heart [L. branchialis (Linné, 1761), Haemobaphes diceraus Wilson, 1917, and Cardiodectes medusaeus (Wilson, 1917)] and also the kidney,

·E-mail: raibaut@univ-montpl.fr either occasionally (Lernaeenicus hemirhamphi Kirtisinghe, 1932) or more permanently (Peroderma cylindricum Heller, 1865)

In the Mediterranean Sea, Peroderma cylindricum is a parasite of the pilchard Sardina pilchardus (Walbaum, 1792). It is known on the Tunisian (Raibaut et al. 1971, Ktari \& Abdelmouleh 1980) and the Algerian (Dollfus 1933, Nunes-Ruivo 1954, Dieuzeide \& Roland 1956) coasts. In European waters of the Mediterranean Sea, P. cylindricum occurs in Spain (Bardan \& Navarro 1952, Larraneta 1957) but has not been found on pilchards from the French Languedocian shores (author's pers. obs.). It has been found in the east, i.e. in Monaco (Brian 1912, Monod 1923), along the coast of Italy (Richiardi 1876, 1880, Brian 1898, 1906, 1912), in Montenegro (Radujkovic \& Raibaut 1989) and also in the Gulf of Volos in Greece (Serbetis 1963). 
In Tunisia, Peroderma cylindricum is present on all coasts but with greatly varying prevalence (Ben Hassine et al. 1990). The highest prevalence, between 27 and $37 \%$ was observed in pilchard sampled from the northern harbours (Tabarka, Bizerte, Ghar al Melh, Tunis); whereas along the eastern coast, starting at Kelibia, it decreased gradually (Sousse, Mahdia) to reach a minimum of $3.7 \%$ in the Sfax area (Fig. 1). These differences in prevalence were originally found by Ben Hassine et al. (1990) and were based on a meristic and morphometric study (Kartas 1981) showing 2 distinct pilchard populations (in the northern and eastern areas). A recent genetical study refuted this finding and showed that pilchards from both north and east of Tunisia belonged to a similar genetical entity. This result was confirmed by a concomitant genetical analysis of $P$. cylindricum infecting these pilchards (Becheikh et al, 1994).

Several studies on the pathogenic effects provoked by this parasite have been carried out. They were mainly concerned with growth and host reproduction.

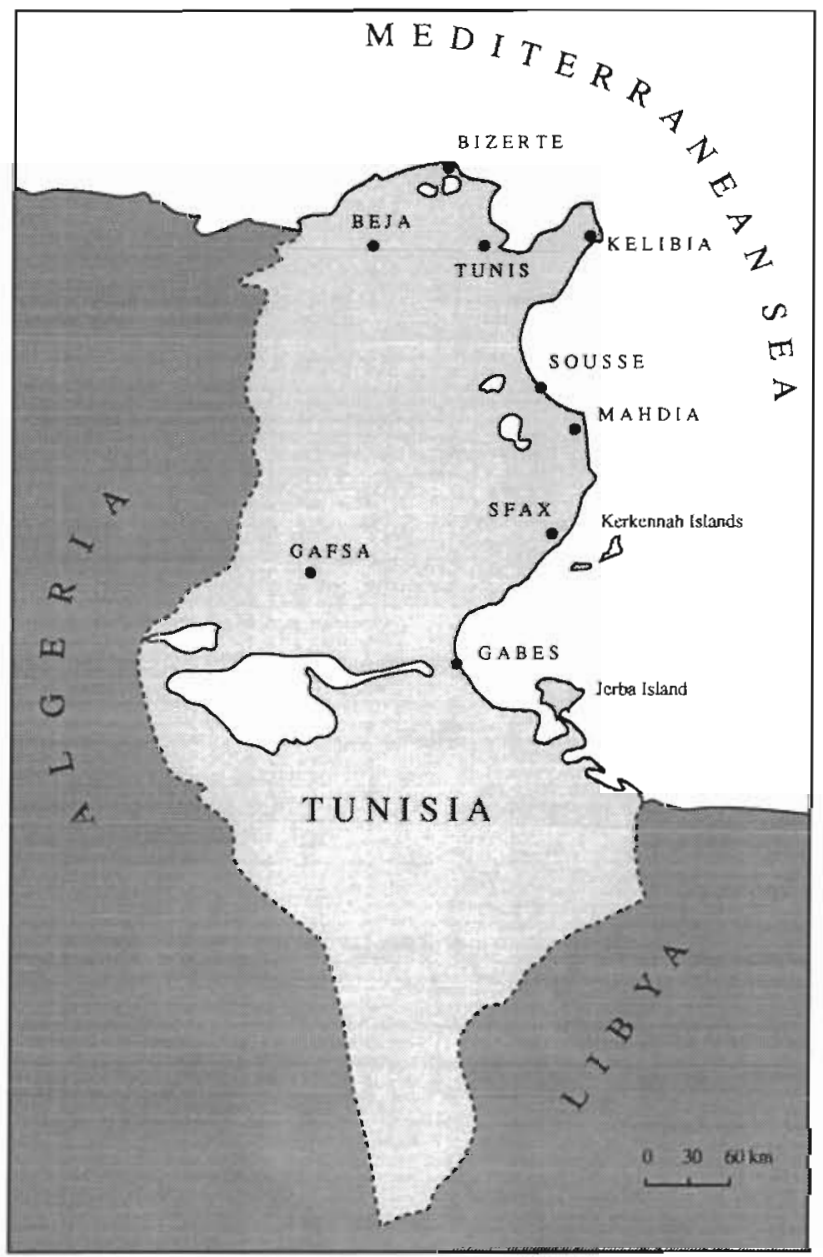

Fig. 1. Samplung area
(Giard 1888, Brian 1912, Wilson 1917, Bardan \& Navarro 1952, Dieuzeide \& Roland 1956, Larraneta 1957, Serbetis 1963, Fernandez Crehuet \& del Val Cordon 1973, Ktari \& Abdelmouleh 1980, Ben Souissi \& Ben Hassine 1991, 1992). The effects on kidney tissue were studied by Monterosso $(1921,1926,1930)$, who made detailed observations. We thought it interesting to carry out further investigations.

\section{MATERIAL AND METHODS}

Parasitized pilchards (about $14 \mathrm{~cm}$ long) were examined within hours of their capture in spring 1993. The removal of Peroderma cylindricum requires accurate dissection under a binocular microscope (particularly for the network of rootlets embedded in the kidney tissue of the host).

For histopathology, healthy kidneys (2 organs) and kidneys parasitized by adult oviferous females $(7$ organs) were fixed in one of the following: Bouin Hollande, Halmi, or Carnoy's fixatives. Some samples, including fragments of hosts' spinal cord, were first decalcified with $5 \%$ trichloroacetic acid. Sections were stained with Masson trichrom, Heidehaim Azan, glychemalun-eosin and Prussian Blue.

For scanning electron microscopy observations, copepods were prefixed in $2.5 \%$ gluteraldehyde at $4{ }^{\circ} \mathrm{C}$ buffered to $\mathrm{pH} 7.2$ with $0.1 \mathrm{M}$ sodium cacodylate, then post-fixed using $1 \%$ osmium tetraoxide in the same buffer for $1 \mathrm{~h}$. Samples were cleaned using a mechanical ultrasound treatment, and dehydrated in a series of ethanol washes with increasing concentration. Samples were critical-point dried and coated in gold.

\section{RESULTS}

\section{Parasite location}

An external view of a pilchard shows the presence of Peroderma cylindricum as revealed by 2 long egg sacs containing unseriated eggs emerging parallel to the body from the fish-host flanks (Fig. 2a). The egg sacs start from the distal end of the parasite, level with a clearly defined orifice with does not show signs of any ulcerative reaction. When the parasite dies, the tegument regenerates, displaying a small, clearly visible cicatricial depression.

Peroderma cylindricum has a characteristic morphology. The female body is composed of 2 parts (Fig. 2b): (1) the trunk, which is large and cylindrical (origin of this species' name) carries 2 long egg sacs on its distal. end (2) the cephalothorax, which is globular, is perpendicularly attached to the subanterior part of the trunk. 



Fig. 2. Peroderma cylindricum parasitizing Sardina pilchardus. (a) External view of a parasitized pilchard showing the lateral emergence of the copepod eggs sacs (arrow). (b) Lateral view of a female extracted from a pilchard. Note the cephalic rootlets (c.r.). (c) Cephalic rootlets (c.r.) shown under scanning electron microscopy. Note the dichotomic ramifications (arrows). (d) Transverse section of a cephalic rootlet under scanning electron microscopy showing 2 superimposed canals (ca)

\section{$2 a$}

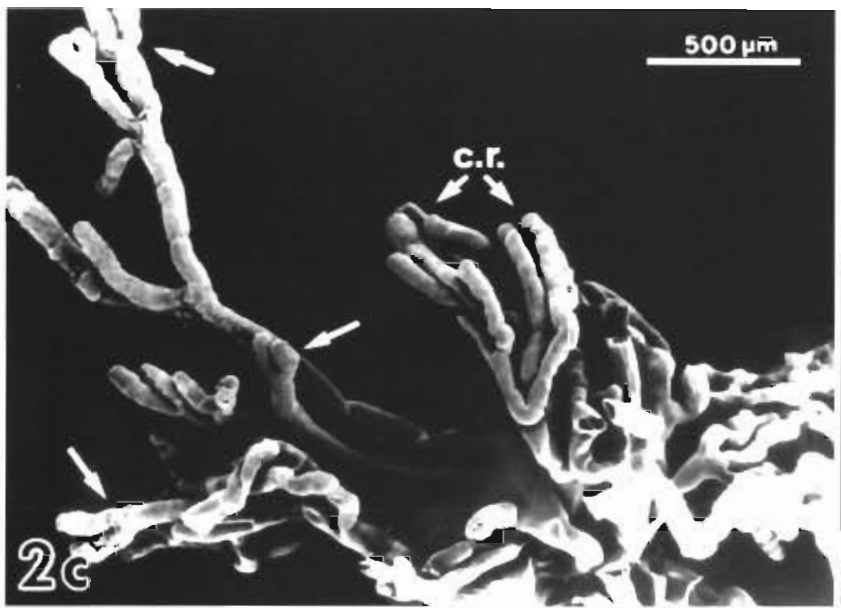

Roughly rounded swellings (cephalothoracic processes) cover almost the entire cephalothorax, except for a narrow mid-ventral area where buccal appendages and thoracic legs are located. Several tubules with dichotomious ramifications extend from the inferior part of the cephalothorax (Fig. 2b, c), constituting an extremely dense network: these are the cephalothoracic rootlets ('appendici rizoidi cefaliche' of Monterosso 1926).
The parasite's trunk has a slanted orientation relative to the longitudinal axis of the fish as defined by its vertebral column (Fig. 3), thus the position of the emergence orifice of the parasite lies slightly posteriorly to its cephalic insertion point.

The copepod trunk, which is covered with a thick cuticle, penetrates through the lateral muscular mass of the pilchard in a gallery-like passage delimited by a fine and regular, reactional fibroblastic layer. The sur-
Fig. 3. Sardina pilchardus. Dissected pilchard showing the position of Peroderma cylindricum in its host. a.s.: anal slit; c.r.. cephalic rootlets; e.s.o.: eggs sac orifice; $r$ rib; t: trunk; v.c.: vertebral column

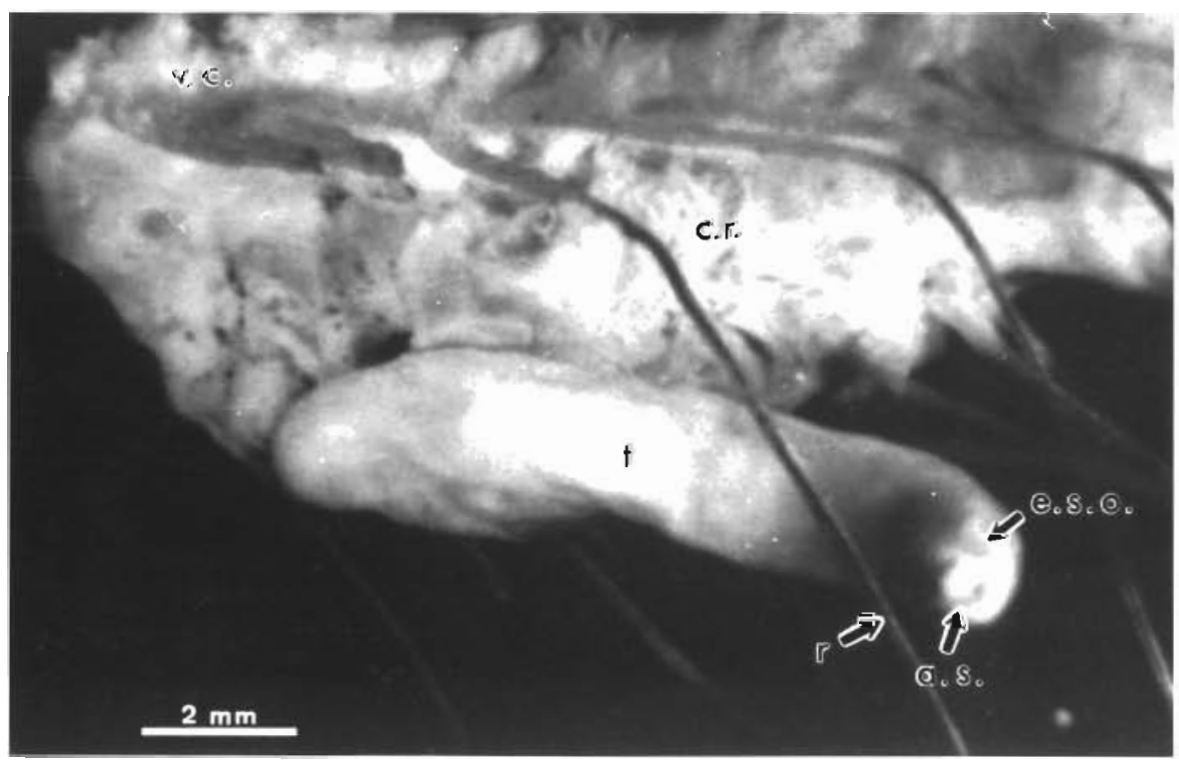


rounding muscles do not seem to be affected by the parasite's presence (Fig. 4a)

\section{Functional anatomy}

Examination of serial sections shows that the genital apparatus occupies a considerable volume in the trunk. Oogenesis is intense (Fig. 4b); the digestive apparatus, which is very compressed, takes up what little room is left. The cell morphology of the gut epithelium is similar to that observed by Honma \& Ho (1988) in another haematophagous pennellid, Lernaeenicus sayori Yamaguti, 1939.

The ovary is paired and functional. The oogonial divisions lead to the formation of ovarian cords (Fig. 4c). Ovocytes commence vitellogenesis in the oviducts. The ovocytes first travel through a spirally coiled area, then become flattened and gather in the bulging portion of the tube (Fig. 4d). Oocyte cytoplasm includes numerous lipid droplets whose presence has also been noted by Honma \& Ho (1988) in Lemaeenicus sayori.

Several parasitic copepods, and particularly Pennellidae (Tirard et al. 1994), show a high fecundity. As pilchards are a pelagic, delicate fish that cannot be kept in captivity, it is impossible to observe females of peroderma cylindricum after the dispersion that follows their first oviposition. However, considering that ovigerous female $P$. cylindricum display ovaries which undergo intense oogonial divisions, one can presume that several ovipositions take place. In another pennellid with ovigerous sacs, Lernaeocera branchialis, Khan (1988) demonstrated that a single oviposition took place, the adult female degenerating afterwards. However, it must be noted that the ovigerous sacs in question are of a considerably bigger size than those of $P$. cylindricum.

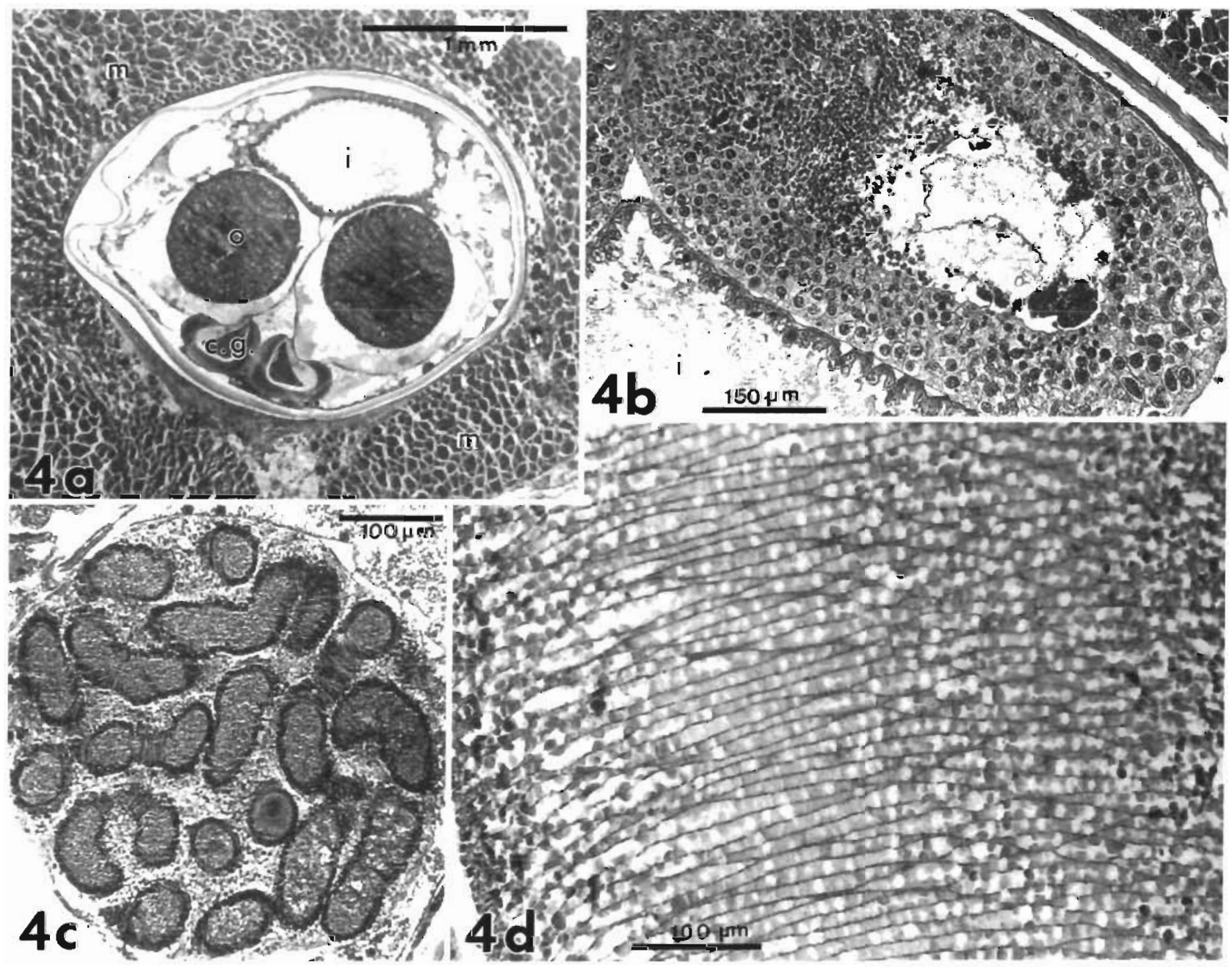

Fig. 4. Peroderma cylindricum. (a) Transverse section of trunk. (b) Transverse section of ovary. (c) Transversal section of ovarian cords. (d) Longitudinal section of oviduct. c.g.: cement gland; i: intestine; m: host muscles; o: oviduct 


\section{Targeted organ}

Healthy kidney

Healthy kidneys are in close contact with the dorsoparietal muscles on either side of the vertebral column and around the swimbladder (Fig. 5a).

The functional and excretory unit of the kidney is the mesonephron. The nephrons are glomerular; glomeruli are small and scarce (Fig. 5b). The glomerulus is surrounded by Bowman's capsule, delimited by a thin epithelium and containing capillaries. The tubule displays, up to its opening in the collecting duct, an epithelial layer whose morphological characteristics vary according to the level (striation on the lumen side, numerous nuclei, different positions and textures). The collecting duct, which has a large lumen, is bordered by connective tissue which is doubled over or does not have smooth muscular cells. Nephrons are surrounded by haemopoietic parenchyma (Fig. 5b).

\section{Parasitized kidney}

Around the area of contact between parasite and kidney, the fibroconnective reaction intensifies while the surrounding myomeres are compressed. Part of the cephalothorax of Peroderma cylindricum penetrates the kidney (Fig. 6a). Cephalic lobes have a syncytial structure (Fig. 6b). The interaction between the host and the parasite is mediated by dense and prolific cephalic rootlets with dichotomic ramifications which are inserted into the kidney's tissues. The presence of these structures provokes alterations in the renal struc- ture. The renal tubules remain only in the organ's periphery. Their number decreases, as does the number of glomeruli (Fig. 6c). Sometimes the parasitized kidneys show large haematomas where rootlets are present (Fig. 6d). These dichotomic rootlets (Fig. 7a) have a syncytial structure on the periphery and contain, depending on their size, at least 2 canals (Fig 2d, 7b) which generally convey secretions (Fig. 7c). We have observed pilchards parasitized by 2 specimens. As a rule, the infection is symmetrical in such cases. Each copepod is inserted into one kidney (Fig. 7d). One parasite appears on the right flank, the other on the left.

\section{DISCUSSION}

Numerous observations made out in Tunisia by Ktari \& Abdelmouleh (1980), Ben Souissi \& Ben Hassine (1991, 1992), and ourselves on infection with Peroderma cylindricum all point to a strictly localised implantation in the anterior part of the mesonephros corresponding to a kidney segment of $7 \mathrm{~mm}$ in length in pilchards with a mean size of $14 \mathrm{~cm}$. No anatomical or histological difference between this part of the kidney and the rest of the organ can explain this preference.

Our study demonstrated that Peroderma cylindricum causes extensive damage in the targeted organ of the host, here the kidney, leading to the destruction of the renal tissue and the appearance of haematomas. Monterosso (1921) noted the pathogenic effects of $P$. cylindricum on the kidneys of its host induced by the presence of rootlets. He observed a compression of the renal tubules gathering in a limited area mainly on the

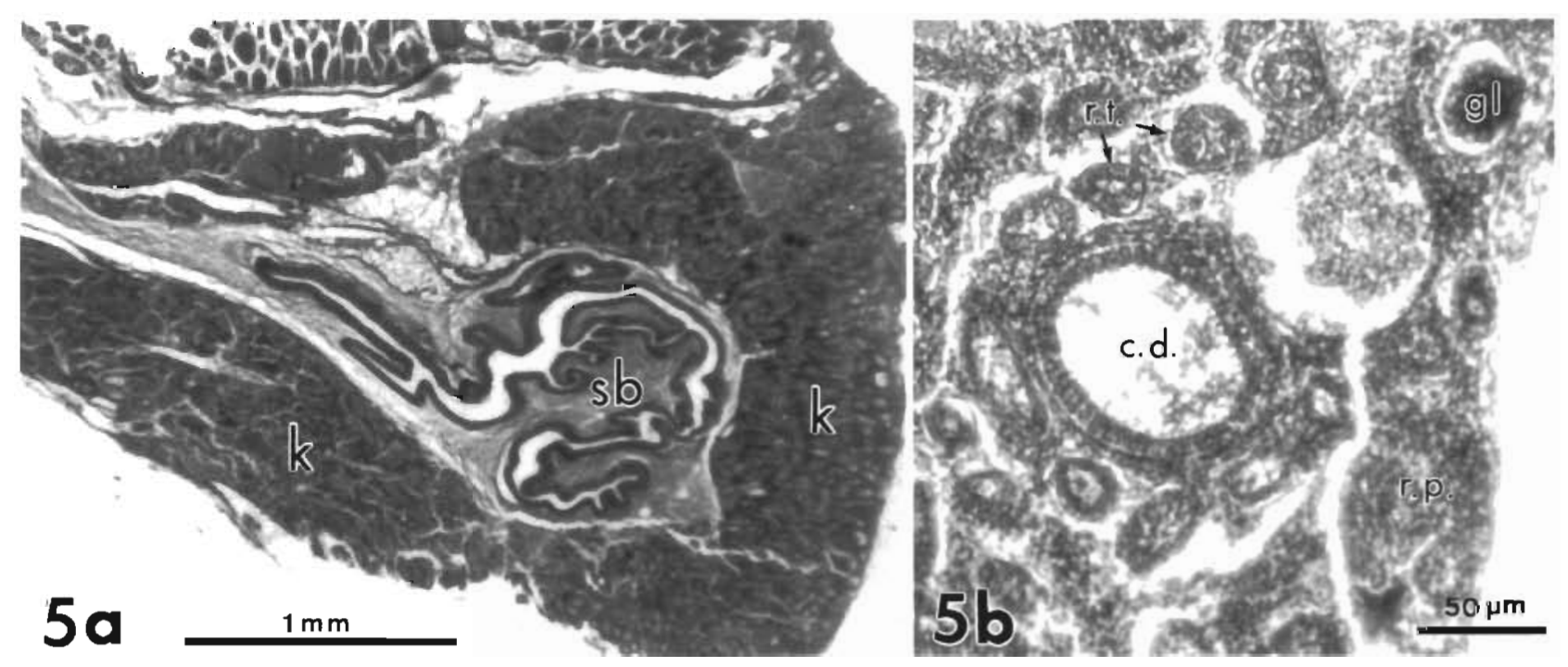

Fig. 5. Sardina pilchardus. (a) Transverse section of kidney (k) through a non-parasitized pilchard at swimbladder (sb) level. (b) Healthy kidney histology showing a collecting duct (c.d.), a glomerulus (gl), renal tubules (r.t.) and renal parenchyma (r.p.) 


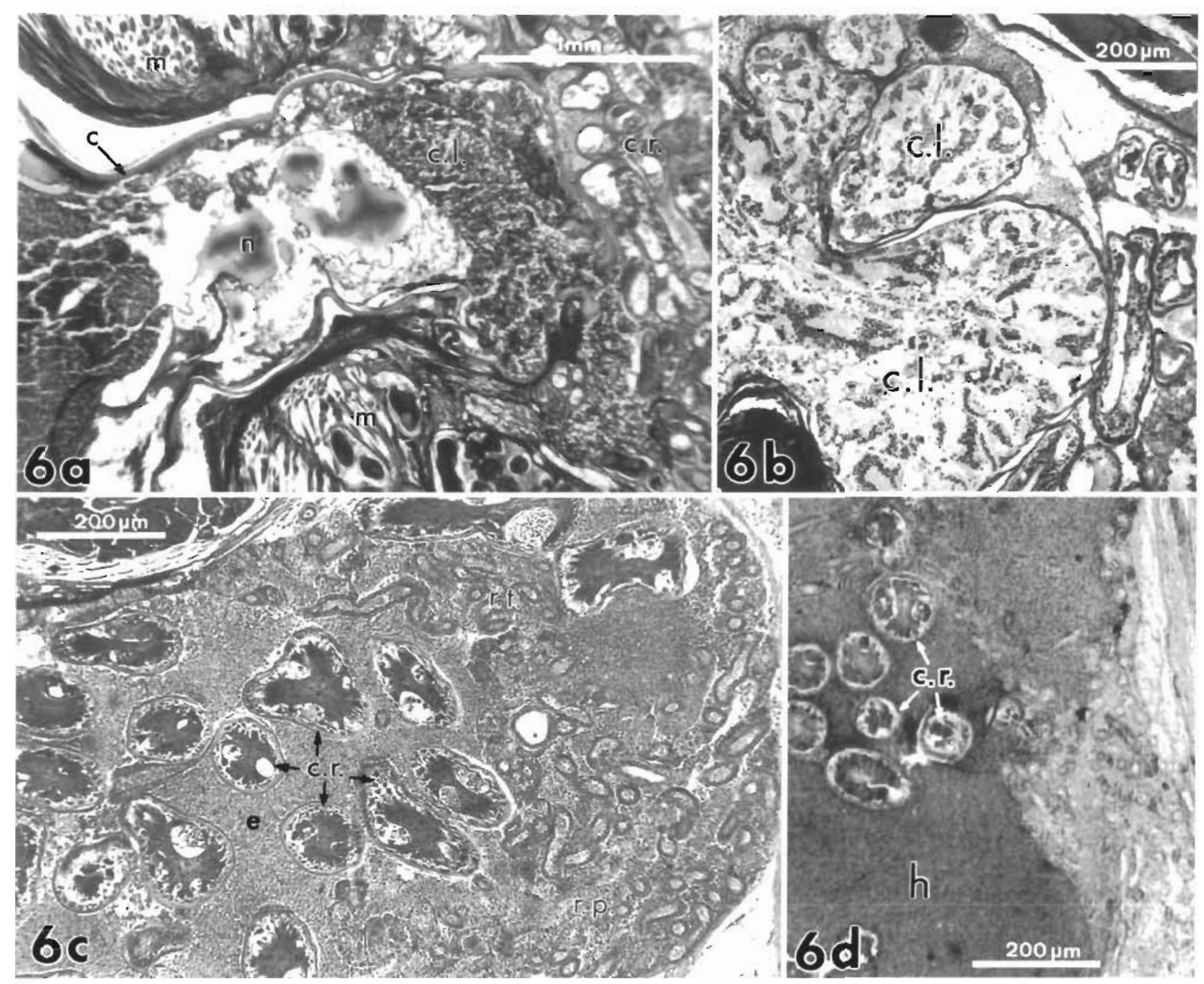

Fig. 6. Sardina pilchardus. Kidney parasitized by Peroderma cylindricum. (a) Area of parasite penetration in the kidney. (b) Cephalic lobes (c.l) detail. ( $c \&$ d) Transverse section of cephalic rootlets (c.r.) in the kidney. c: cuticle; e: erythrocytes; h: haematoma m: muscles; n: neck of $P$. cylindricum; r.p. renal parenchyma; r.t.: renal tubules

periphery of the organ. Accumulation of erythrocytes around the renal tubules as well as local haemorrhage are also mentioned. Natarajan \& Nair (1973) report on another instance of fish kidneys being infected by a copepod, Lernaeenicus hemirhamphi. This copepod, a member of the family Pennellidae, parasitises Hemiramphus xanthopterus (Valenciennes) but -in contrast with $P$. cylindricum - is not an obligate parasite of kidneys. Natarajan \& Nair (1973) demonstrated that on a sample of 155 fish parasitized by L. hemirhamphi almost $44 \%$ of the parasites were inserted into the kidneys, while the others were mainly embedded in the muscular mass $(46.4 \%)$. Unlike $P$. cylindricum, $L$. hemirhamphi does not possess cephalic rootlets but rather 3 cephalothoracic antlers, common in pennellids. In this case, it is the presence of the anterior part of the copepod in the kidneys of the host that causes the damage to their structure. In addition to the fibroconnective reaction around the parasite, degeneration of renal tubules and blood dilation of vessels were observed.

The presence of a dense and prolific network of cephalic rootlets characterizes species of the genus Peroderma. These structures contain 2 canals, observed by Monterosso $(1921,1926)$, who compared them to afferent and to efferent vessels. It has been established that these canals are filled with a liquid containing secretions. As these rootlets are inserted into the renal parenchyma, some soaking in haemorrhagic parts, it is unlikely that they have only an anchoring role. What could their functions be? Monterosso (1921) assumed originally that the rootlets' function was that of nutrient absorption, as well as excretion and secretion. Later, he rejected the possi- 




Fig. 7. Peroderma cylindricum parasitizing Sardina pilchardus. (a) Longitudinal section of a cephalic rootlet showing dichotomy (b) Transverse section of a cephalic rootlet showing both superposed canals. (c) Transversal and longitudinal sections of cephalic rootlets showing signs of secretions in the canals. (d) Bilateral infection of pilchard's kidneys. ca: canals; c.r.: cephalic rootlets; e: erythrocytes; h: haematoma; k: kidney; m: muscles; t.s.p.. transverse section of parasite

bility of absorption of nutrients from the host's blood accepting at the very most the possibility that oxygen and perhaps water, are absorbed (Monterosso 1926). In support of this hypothesis, this Italian author compared the structure of the rootlets in the genus Peroderma to that of abdominal processes in a species of the genus Pennella, characteristic of the species of this genus as well as of the genus Lernaeolophus. Monterosso established the presence of 'una rassomiglianza di structura veramente impressionante', an observation confirmed more recently by Honma \& Ho (1988) in Lernaeolophus aceratus Ho \& Honma, 1983. Nevertheless, there is a difference in the cuticle of the wall of these formations, which are thin in the rootlets but thick in the abdominal processes. Moreover, it should be kept in mind that the former are inside the kidney, whereas the latter are outside the host in the sea water, a fact that prompted the idea that they may play a respiratory role.

Another example of a haematophagous pennellid copepod is Cardiodectes medusaeus, which also displays a holdfast apparatus comprising numerous frontal processes found in the bulbus arteriosus of its lanternfish host (Myctophidae). Perkins (1985) showed in a detailed electron microscopy study that 'the attachment organ of Cardiodectes medusaeus functions in the digestion of host blood, synthesis and storage of ferritin, and possibly, absorption and secretion: We did not detect in Peroderma cylindricum any sign of ferritin resulting from digestion of pilchard haemoglobin in $P$. cylindricum rootlets or digestive tract; unless the amount of ferritin was too small to be observed with Prussian Blue, the reactive agent used.

A similar rootlet network is known in Rhizocephala. From an electron microscopy study of these formations, Bresciani \& Lützen (1980) concluded that their role is essentially trophic. Using tracers, Payen et al. (1983) observed the passage of substances in the rootlets of sacculinid rhizocephalans and showed their various functions: synthesis, absorption and transfer of substances. However, we must remember that these crustaceans are devoid of a digestive tract.

Several copepods, parasites of either invertebrates or fishes, have cephalic finger-like, tentaculiform or rootlike structures. This is the case for the following: Haemocera danae (Claparède 1863), endoparasite of the annelid Salmacina dysteri; Phyllodicola petiti (Delamare Deboutteville \& Laubier 1960), parasite of phyllodocid annelids; Gonophysema gullmarensis, parasite of the ascidian Ascidiella aspersa; Phrixocephalus cincinnatus Wilson 1908, a pennellid copepod found embedded in the eye of its fish-host Ather- 
estes stomias; and for Cardiodectes medusaeus, previously mentioned. All these structures are involved in metabolite exchange processes between the copepod and its host, perhaps sometimes with a trophic purpose, although this has never been confirmed.

There is no possibility of experimenting on adult Sardina pilchardus specimens as pilchards cannot be kept in captivity. Only ultrastructural study will allow consideration of the probable impact of Peroderma cylindricum rootlets on the renal parenchyma of this fish. On the other hand, the onset of infection can be investigated by following the development of the rootlets in young females. $P$ cylindricum, like most pennellids, has a biological cycle which is probably heteroxenous, the details of which we are trying to work out. The possibility of the existence of a first host is currently being investigated. Larval stages of a pennellid on some cephalopod gills (Sepia officinalis Linnaeus, S. elegans Orbigny and Loligo vulgaris Lamark) from Algerian coasts have been reported by Rose \& Hamon (1953).

The present study demonstrates that Peroderma cylindricum induces extensive injury by inserting itself into the targeted organ of its host, the kidney. Our observations were carried out on wild pilchards parasitized under natural conditions. The physiology of these pelagic fish, which are prey to numerous predators (ichthyophagous birds, carnivorous fishes such as Scombridae or Belonidae), does not seem to be disturbed by the presence of the copepod, although it is beyond doubt that the parasitized renal area remains only partly, if at all, functional. Injury to a very small part of the kidney does not significantly affect the function of this organ. The pilchards observed during our study carried only one parasite. There is nothing to exclude the presence of several copepods. Infection intensities from 1 to 4 were observed among the pilchards sampled in Tunisia (1917 samples). The intensity of 1 copepod per host was by far the most frequent $(86.3 \%)$. Other intensities were much less frequent: 12.4, 1 and $0.3 \%$ for 2,3 and 4 parasites, respectively (Ben Souissi \& Ben Hassine 1992). It is obvious that the decrease in the number of pilchards parasitized by several $P$. cylindricum can be interpreted as a sign of mortality in fish thus infected. Also, Ben Hassine et al. (1990) demonstrated that the pilchards most frequently parasitized by $P$. cylindricum had a mean size of 14 to $15 \mathrm{~cm}$, and presumably were aged 2 to 3 yr (Kartas 1981). Based on our knowledge concerning the time of development for young females in premetamorphosis and up to the adult stage in Pennellidae (9 to 10 mo for Lernaeocera branchialis according to Khan 1988), it is likely that the infection of pilchards by $P$. cylindricum occurs mostly in specimens aged. 1 to 2 yr. It is probably in these year classes, and especially in young specimens, that the highest mortality rates occur
Acknowledgements. The authors thank R. Marin, photographic technician, for his contribution to the present work, and $T$. Hajji, PhD student, who provided the photograph of Perpderma cylindricum (Fig. 2b).

\section{LITERATURE CITED}

Bardan E, Navarro F (1952) Estudios sobre la sardina de Malaga en 1951 y consideraciones sobre la variabilidad de su formula vertebral. Bol Inst Espanol Oceanogr 57:3-23

Becheikh S, Raibaut A, Euzet S, Ben Hassine OK (1994) Etude biosystématique de deux populations de Téléostéens (Sardina pilchardus) et de leurs Copépodes parasites (Peroderma cylindricum) sur les côtes tunisiennes. Parasite $1: 279-282$

Ben Hassine OK, Raibaut A, Ben Souissi J, Rousset V (1990) Morphologie de Peroderma cylindricum Heller, 1865, Copépode parasite de la Sardine, Sardina pilchardus (Walbaum, 1792) et quelques aspects de son écologie dans les eaux cottières tunisiennes. Ann Sci Nat Zool, Paris (Ser 13) 11:9-16

Ben Souissi J, Ben Hassine OK (1991) Action pathogène de Peroderma cylindricum Heller, 1865 (Copépode parasite) sur la condition et le développement des gonades de Sardina pilchardus (Walbaum, 1792) des côtes tunisiennes. Cah Biol Mar Roscoff 32:234

Ben Souissi J, Ben Hassine OK (1992) Aspects écologiques des copépodoses de la sardine, Sardina pilchardus (WaIbaum, 1792) des côtes tunisiennes. Rev Fac Sci Tunis 5 (Ser D): $1-12$

Bresciani J, Dantzer V (1980) Fine structural localization of acid phosphatase in the root system of the parasite Clistosaccus paguri (Crustacea, Rhizocephala). Elect Microsc 2:290-291

Bresciani J, Lützen J (1980) Electron microscopy of the root system of the parasites Lernaeodiscus porcellanae. Peltogaster paguri, Clistosaccus paguri and Sacculina carcini (Crustacea, Rhizocephala). Electr Microsc 2:220-221

Brian A (1898) Catalogo di copepodi parassiti dei pesci della Liguria. Boll Mus Zool Anat Comp Genova 61:1-27

Brian A (1906) Copepodi parassiti dei pesci d'Italia. Stab. tipolitografico R. Istituto Sordomuti, Genova

Brian A (1912) Copépodes parasites des poissons et des échinides provenant des campagnes scientifiques de SAS le Prince Albert $1^{\text {er }}$ de Monaco. Résult Camp scient Prince Albert $1^{\text {er }} 38: 1-58$

Dieuzeide R, Roland J (1956) Observations réalisées sur les sardines (Sardina pilchardus Walbaum) de la baie de Castiglione parasitées par Peroderma cylindricum Heller. Bull Trav Stat Aquic Pêche Castiglione 8:227-249

Dollfus RP (1933) Sur quelques parasites de poissons récoltés à Castiglione (Algérie). Bull Trav Stat Aquic Pêche Castiglione 2:199-279

Fernandez Crehuet R, del Val Cordon MJ (1973) Consideraciones biologico-quimicas sobre la sardina (Sardina pilchardus Walb.) normal y parasitada de Malaga. BoI Inst Español Oceanogr 160:1-24

Giard A (1888) Sur le Peroderma cylundricum Heller, copépode parasite de la sardine. CR Acad Sci Paris 107 23:929-931

Honma Y. Ho JS (1988) Histological studies on two species of the Pennellidae (Copepoda) parasitic on Japanese marine fishes. Rep Sado Mar Biol Stn Niigata Univ 18:33-46

Kartas F (1981) Les clupeidés de Tunisie. Caractéristiques biométriques et biologiques. Etude comparée des populations de l'Atlantique est et de la Méditerranée. Thèse d'Etat, Fac Sci Tunis 
Khan RA (1988) Experimental transmission, development, and effects of a parasitic copepod, Lemaeocera branchialis, on Atlantic cod, Gadus morhua. J Parasitol 74(4) 586-599

Ktari MH, Abdelmouleh A (1980) Note sur la présence el les effets du copépode Peroderma cylindricum Heller, 1868, parasite de la sardine Sardina pilchardus (Walbaum, 1792) des cotes tunisiennes. Bull Inst Nat Sci Tech Océanogi Pêche Salammbò 7:103-112

Larraneta MG (1957) Présence du parasite Peroderma cylindricum Heller sur la sardine de Castellon et d'Alicante Deb Doc Tech Cons Gén Péches Médit FAO 4:109-112

Monod T (1923) Notes carcinologiques (parasites et commensaux). Bull Inst Océanogr (Monaco) 427:1-23

Monterosso B (1921) Contributo allo studio di Peroderma cylindricum Heller, copepode parassita di Clupea pilchardus Art. Atti Accad Gioenia (Ser 5) 13 9:1-19

Monterosso B (1926) Contributo alla conoscenza dei copepodi parassiti. Le appendici rizoidi cefaliche di Peroderma cylindricum' Heller. Arch Biol 36 2:167-223

Monterosso B (1930) Contributo alla conoscenza dei copepodi parassiti. L'intestino di Peroderma cylindricum Heller. Arch Zool Ital 14 2-4:169-225

Natarajan P, Nair NB (1973) Observations on the nature of attack of Lernaeenicus hemirahmphi Kirtisinghe on Hemirhamphus xanthopterus (Val.). J Anim Morphol Physiol 20(1):56-63

Nunes-Ruivo LP (1954) Copépodes parasites de poissons. Résultats campagne Pr. Lacaze Duthiers. Vie Milıeu (Suppl) 3:115-138

Payen GG, Rubiliani C, Hubert M, Poulhe R, Turquier $Y$, Chassard-Bouchaud C (1983) Mise en évidence des fonc-

Responsible Subject Editor: W. Körting, Hannover, Germany tions de synthèse, d'absorption et de transfert de substances par les racines des Rhizocéphales Sacculinidae; premières données biochimiques et cytochimiques. 2 Parasitenkd 69:255-269

Perkins PS (1985) Iron crystals in the attachment organ of the erythrophagous copepod Cardiodectes medusaeus (Pennellidae). J Crustacean Biol 5 (4):591-605

Radujkovic BM, Raibaut A (1989) Copépodes parasites des poissons des côtes du Monténégro (Adrıatique Sud). Parassitologia 31:1-24

Raibaut A, Ben Hassine OK, Maamouri K (1971) Copépodes parasites des poissons de Tunisie (première série). Bull Inst Nat Sci Tech Océanogr Pêche Salammbô 2 2:169-197

Richiardi S (1876) Intorno al Peroderma cylindricum dell' Heller e sopra due specie nuove dell'genere Philichthys. Atti Soc Tosc Sci Nat 2:189-201

Richiardi S (1880) Contribuzione alla fauna d'Italia. I Catalogo sistematico dei crostacei che vivono sul corpo di animali aquatici. Catalogo Sez Ital Esposiz internaz di Pesca Berlino:147-152

Rose M, Hamon M (1953) A propos de Pennella varians Steenstrup \& Lütken, 1861, parasites des branchies de Céphalopodes. Bull Soc Hist Nat Afr Nord 44 (5-6):172-183

Serbetis CD (1963) Le parasite Peroderma cylindricum Heller sur les sardines de Volos. Deb Doc Tech Cons Gén Pêches Médit FAO 7:491-492

Tirard C, Renaud F, Raibaut A. (1994) Signification évolutive de l'hétéroxénie chez les copépodes parasites. Ann Sci Nat, Zool, Paris (Ser 13) 2 15:77-82

Wilson CB (1917) North American parasitic copepods belonging to Lernaeidae, with a revision of the entire family. Proc US Nat Mus 53:1-150

Manuscript first received: June 4, 1996

Revised version accepted: September 14, 1996 